\title{
IbM PEMBUATAN PUPUK ORGANIK DIPERKAYA DI KELOMPOK PETERNAK SAPI DALAM RANGKA MENUJU PERTANIAN ORGANIK DI DESA SUKOHARJO, TIRTOMOYO, WONOGIRI
}

\author{
Sudadi dan Suryono \\ Program Studi Ilmu Tanah / Fakultas Pertanian, Universitas Sebelas Maret Surakarta \\ Email : sudadi_uns@yahoo.com
}

\begin{abstract}
ABSTRAK
Program IbM ini bekerjasama dengan dua mitra, yaitu: (1) Kelompok Tani "Bhakti Karya", dan (2) Kelompok Tani "Ngudi Makmur". Mitra (1) berlokasi di dusun Blaraksari, Desa Sukoharjo, Kecamatan Tirtomoyo, Kabupaten Wonogiri, dengan jarak tempuh sekitar $65 \mathrm{~km}$ dari Fak. Pertanian UNS. Bidang usaha yang dikembangkan oleh mitra (1) tersebut adalah usaha peternakan sapi dan pertanian tanaman padi. Mitra (2) berlokasi di dusun Sukoharjo, Desa Sukoharjo, Kecamatan Tirtomoyo, Kabupaten Wonogiri dengan jarak tempuh sekitar $65 \mathrm{~km}$. Bidang usaha yang dikembangkan oleh mitra (2) tersebut adalah peternakan sapi dan pertanian tanaman padi. Lokasi kedua mitra sangat berdekatan, hanya sekitar $0,8 \mathrm{~km}$. Permintaan konsumen terhadap pupuk organik dalam menuju pertanian organik sangat tinggi, belum mampu dipenuhi oleh kedua mitra usaha tersebut.Permasalahan Mitra 1 ("Bhakti Karya") dan Mitra 2 ("Ngudi Makmur")dalam kegiatan IbM ini menghadapi permasalahan utama yaitu banyaknya kotoran sapi yang belum termanfaatkan, produksi limbah ternak sapi (kotoran sapi) yang sangat tinggi, yaitu sekitar $100 \mathrm{~kg}$ limbah per hari ( 3 ton per bulan) pada masing-masing mitra, dan jika hal ini dibiarkan akan menjadi tumpukan kotoran sapi yang sangat berbau yang mengganggu lingkungan, apabila dikelola/diolah/difermentasi diperkaya dengan bakteri perombak bisa digunakan sebagai pupuk organik yang sangat bermutu. Dalam usaha peternakan sapi ini ingin mengarah pada peternakan yang ramah lingkungan sehingga tidak menjadi masalah di masyarakat. Apabila dikelola dengan baik akan dapat digunakan sebagai pupuk organik yang sangat bermanfaat dan dapat meningkatkan kesuburan tanah secara terus menerus dan apabila diberikan terus menerus akan menuju pertanian organik berkelanjutan. Hasil kegiatan IbM ini dapat digunakn untuk mengatasi permasalahan yang dihadapi mitra usaha dengan memanfaatkan pupuk kandang dari mitra (1) dan mitra (2) sebagai pupuk organik yang diperkaya di kelompok kelompok peternak sapi dalam rangka menuju pertanian organik di Desa Sukoharjo, Tirtomoyo, Wonogiri.
\end{abstract}

Kata kunci : pupuk organik diperkaya,kelompok peternak sapi,pertanian organik

\section{PENDAHULUAN}

Program IbM ini bekerjasama dengan dua mitra, yaitu: (1) Kelompok Tani "Bhakti Karya", dan (2) Kelompok Tani "Ngudi Makmur". Mitra (1) berlokasi di dusun Blaraksari, Desa Sukoharjo, Kecamatan Tirtomoyo, Kabupaten Wonogiri, dengan jarak tempuh sekitar $65 \mathrm{~km}$ dari Fak. Pertanian UNS. Bidang usaha yang dikembangkan oleh mitra (1) tersebut adalah usaha peternakan sapi dan pertanian tanaman padi. Mitra (2) berlokasi di dusun Sukoharjo, Desa Sukoharjo, Kecamatan Tirtomoyo, Kabupaten Wonogiri dengan jarak tempuh sekitar $65 \mathrm{~km}$. Bidang usaha yang dikembangkan oleh mitra (2) tersebut adalah peternakan sapi dan dan pertanian tanaman padi. Lokasi kedua mitra sangat berdekatan, hanya sekitar $0,8 \mathrm{~km}$. Permintaan terhadap pupuk organik dalam menuju pertanian 
organik sangat tinggi, belum mampu dipenuhi oleh kedua mitra usaha tersebut yang perlu ditingkatkan terus, baik kualitas maupun kuantitas.

$$
\text { Kelompok Tani "Bhakti }
$$

Karya"merupakan suatu kelompok tani yang bergerak dalam usaha peternakan sapi. Kelompok tani ini terdiri dari 15 anggota, yang masing-masing anggota rata-rata memiliki 2 sampai 3 ekor sapi.Manajemen yang dikembangkan dalam kelompok tani ini berdasarkan kegotongroyongan/ kebersamaan.

Kelompok Tani "Ngudi Makmur" merupakan suatu kelompok tani yang bergerak dalam usaha peternakan sapi. Kelompok tani ini terdiri dari 15 anggota, yang masing- masing anggota rata-rata memiliki 2 sampai 3 ekor sapi.Manajemen yang dikembangkan dalam kelompok tani ini juga berdasarkan kegotongroyongan/ kebersamaan.

Permasalahan Mitra 1 ("Bhakti Karya") dan Mitra 2 ("Ngudi Makmur") adalah banyaknya kotoran sapi yang belum termanfaatkan, produksi limbah ternak sapi (kotoran sapi) yang sangat tinggi, yaitu sekitar $100 \mathrm{~kg}$ limbah per hari (3 ton per bulan) pada masing-masing mitra, dan jika hal ini dibiarkan akan menjadi tumpukan kotoran sapi yang sangat berbau yang mengganggu lingkungan, apabila dikelola/diolah/difermentasi diperkaya dengan bakteri perombak bisa digunakan sebagai pupuk organik yang sangat bermutu. Dalam usaha peternakan sapi ini ingin mengarah pada peternakan yang ramah lingkungan sehingga tidak menjadi masalah di masyarakat. Apabila dikelola dengan baik akan dapat digunakan sebagai pupuk organik yang sangat bermanfaat dan dapat meningkatkan kesuburan tanah secara terus menerus dan apabila diberikan terus menerus akan menuju pertanian organik berkelanjutan.
Rencana kegiatan IbM ini berusaha untuk mengatasi permasalahan yang dihadapi mitra usaha dengan memanfaatkan pupuk kandang dari mitra (1) dan mitra (2) untuk dimanfaatkan sebagai pupuk organik. Penerapan teknologi yang diusulkan akan menghasilkan kegiatan peternakan sapiyang ramah lingkungan dan saling menguntungkan.

\section{METODE}

Solusi yang ditawarkan untuk mengatasi permasalahan yang dihadapi mitra adalah membuat pupuk organik dengan memanfaatkan kotoran sapi yang dikomposkan dengan menggunakan starbio/bakteri dekomposer yang dapat membuat unsur-unsur hara lebih tersedia bagi tanaman dan dapat digunakan sebagai pupuk organik yang sangat bermanfaat dan dapat meningkatkan kesuburan tanah secara terus menerus dan apabila diberikan terus menerus akan menuju pertanian organik berkelanjutan.

Memelihara sapi sangat menguntungkan, karena tidak hanya menghasilkan daging atau susu tetapi juga menghasilkan pupuk kandang. Kotoran sapi memiliki nilai ekonomis karena termasuk pupuk organik yang dibutuhkan oleh semua jenis tumbuh- tumbuhan. Sebagian besar kotoran hewan dapat digunakan untuk pupuk setelah mengalami pengomposan yang matang, yaitu bila secara fisik (warna, rupa, tekstur dan kadar air) tidak serupa dengan bahan aslinya, secara kimia memiliki kandungan bahan organik: $60-70 \%, \mathrm{~N}: 2 \%$, P2O5: $1 \%$, K2O: $1 \%$. Jenis kotoran hewan yang umum digunakan adalah kotoran sapi, kerbau, kelinci, ayam, dan kambing. Tidak ada bukti yang signifikan mengenai keunggulan masing-masing jenis kotoran hewan, tetapi secara umum kotoran sapi banyak digunakan sebagai pupuk kandang karena ketersediaannya lebih banyak 
dibandingkan kotoran hewan lain. (Setiawan, 1998).Pupuk kandang selain mengandung unsur-unsur zat hara serta mineral juga bisa memperbaiki struktur tanah seperti halnya pupuk kompos (Rahardi et al., 1995).Kelebihan pupuk kandang adalah dapat meningkatkan humus, memperbaiki struktur tanah, dan meningkatkan kehidupan mikroorganisme pengurai (Zulkarnain, 2009). Cara kerja dari pupuk kandang ini cara kerjanya yang lamban. Oleh karena itu ia amat cocok digunakan sebagai pupuk dasar (Hidayat dan Darwin, 2008).

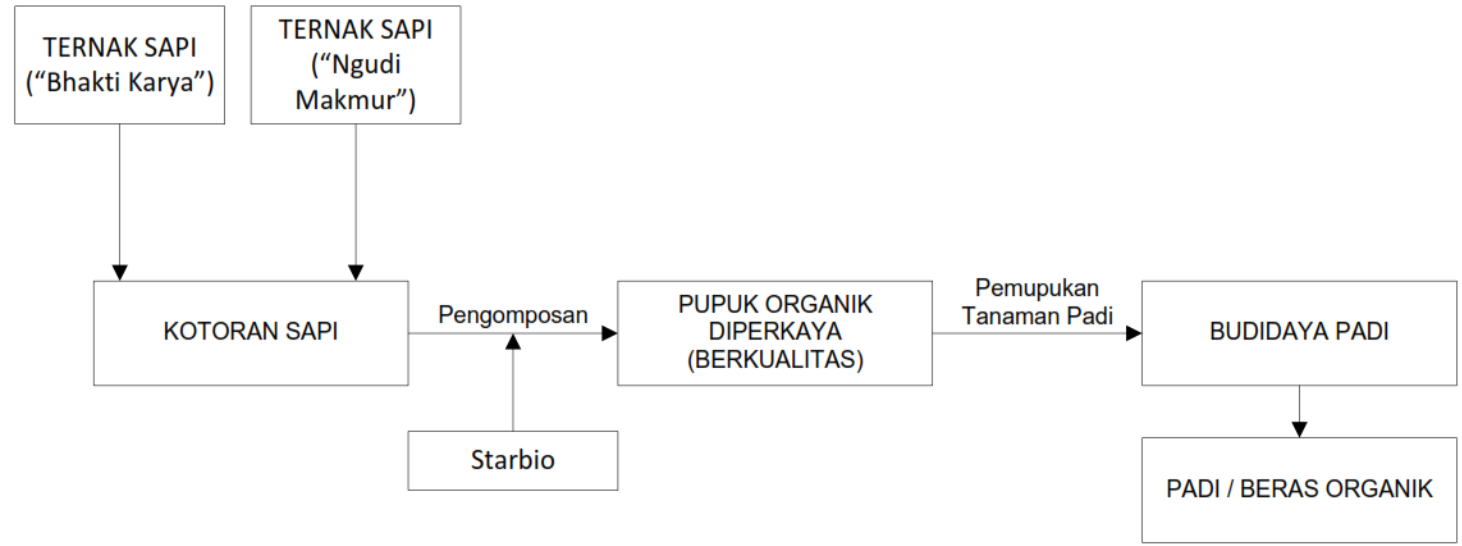

Gambar 1. Gambaran Ipteks yang akan ditransfer kepada kedua mitra

Rencana Kegiatan dan Langkah-langkah Pelaksanaan

Adapun kegiatan yang dilaksanakan meliputi: Survey awal untuk mengetahui tingkat pengetahuan mitra, kondisi lingkungan dan proses perijinan; Koordinasi denganmitra untuk menentukan waktu, tempat pelaksanaan serta materi yang dibutuhkan mitra; Penyiapan peralatan dan perlengkapan pelatihan; Penyusunan modul/materi pelatihan; Praktek pembuatan pupuk organik dengan memanfaatkan kotoran sapi yang dikomposkan dengan menggunakan starbio/bakteri dekomposer yang dapat membuat unsur-unsur hara lebih tersedia bagi tanaman dan dapat digunakan sebagai pupuk organik.

\section{Partisipasi Mitra Dalam Pelaksanaan Program}

Partisipasi mitra dalam pelaksanakan program IbM ini meliputi:Penyediaan kotoran sapi sebagai bahan pembuatan pupuk organic, dan Penyediaan sumberdaya manusia sebagi subyek untuk dilatih berbagai kegiatan program ini.

\section{HASIL YANG DICAPAI}

Hasil kegiatan IbM ini dapat digunakan untuk mengatasi permasalahan yang dihadapi mitra usaha dengan memanfaatkan pupuk kandang dari mitra (1) dan mitra (2) sebagai pupuk organik yang diperkaya di kelompok kelompok peternak sapi dalam rangka menuju pertanian organik di Desa Sukoharjo, Tirtomoyo, Wonogiri.

Permasalahan Mitra 1 ("Bhakti Karya") dan Mitra 2 ("Ngudi Makmur")dalam kegiatan IbM ini menghadapi permasalahan utama yaitu banyaknya kotoran sapi yang belum termanfaatkan, produksi limbah ternak sapi (kotoran sapi) yang sangat tinggi, yaitu sekitar $100 \mathrm{~kg}$ limbah per hari (3 ton per bulan) pada masing-masing mitra, dan jika hal ini dibiarkan akan menjadi tumpukan kotoran sapi yang sangat berbau yang mengganggu lingkungan, apabila dikelola/ 
diolah/difermentasi diperkaya dengan bakteri perombak bisa digunakan sebagai pupuk organik yang sangat bermutu. Dalam usaha peternakan sapi ini ingin mengarah pada peternakan yang ramah lingkungan sehingga tidak menjadi masalah di masyarakat. Apabila dikelola dengan baik akan dapat digunakan sebagai pupuk organik yang sangat bermanfaat dan dapat meningkatkan kesuburan tanah secara terus menerus dan apabila diberikan terus menerus akan menuju pertanian organik berkelanjutan.

Kegiatan pengabdian ini dilakukan melalui penyuluhan dan prektek langsung untuk mengatasi permasalahan mitra yang ditunjukkan pada gambar-gambar berikut :

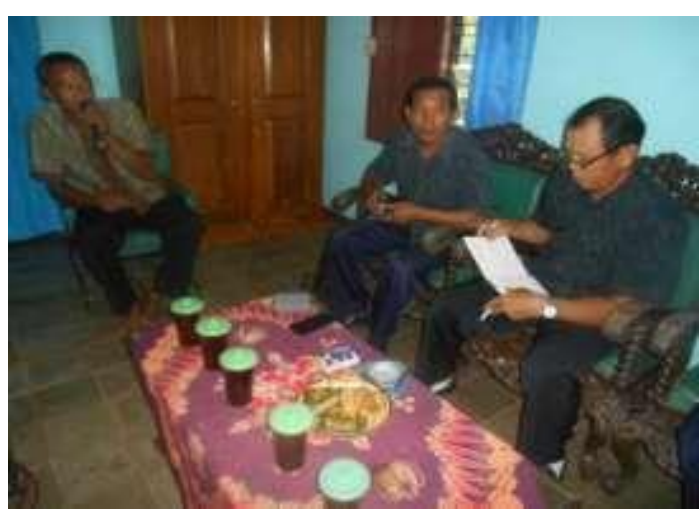

Gambar 1. Koordinasi dengan Mitra

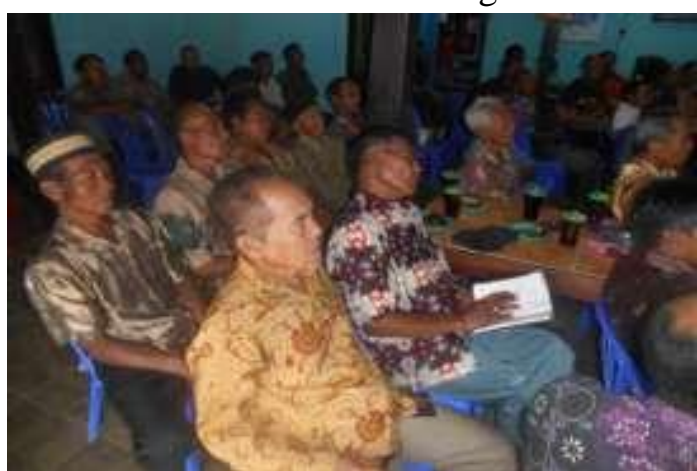

Gambar 2. Penyuluhan Pembuatan Pupuk Organik yang diperkaya

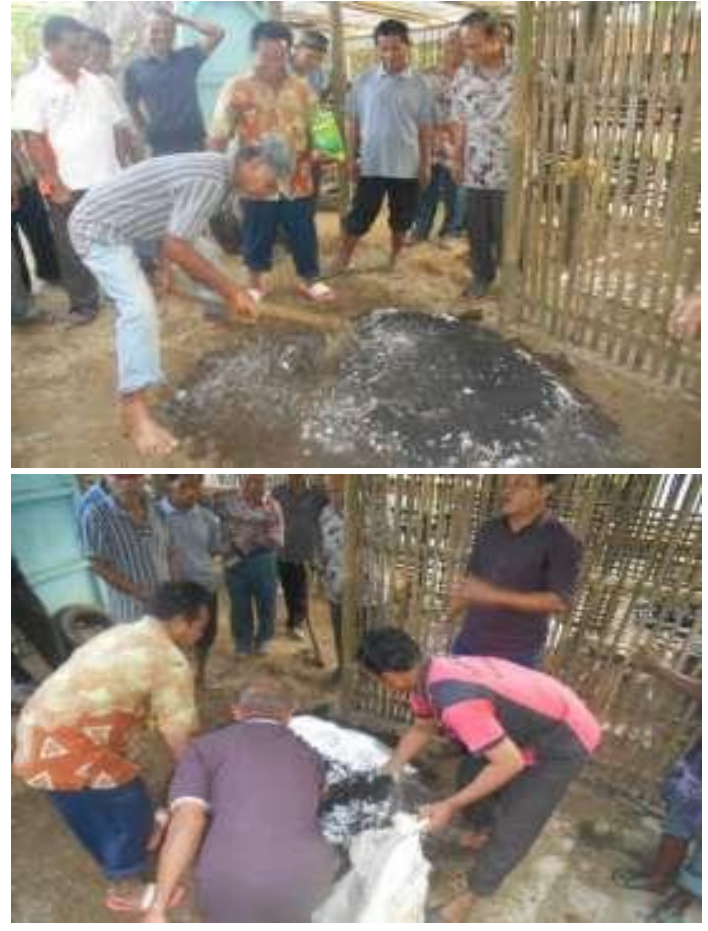

Gambar 3. PraktekPembuatan Pupuk Organik yang diperkaya

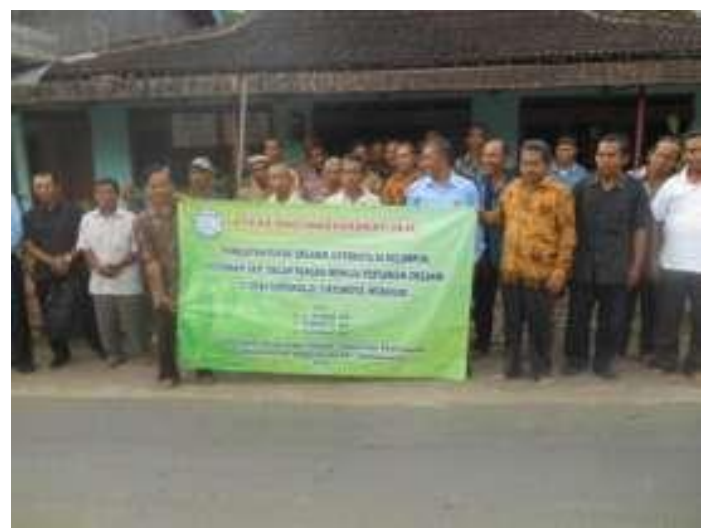

Gambar 4. Foto bersama Tim Pengabdi dengan Kedua Mitra

\section{KESIMPULAN}

Melalui kegiatan IbM ini dapat mengatasi permasalahan yang dihadapi mitra usaha dengan memanfaatkan pupuk kandang sebagai pupuk organik yang diperkaya di kelompok kelompok peternak sapi dalam rangka menuju pertanian organik di Desa Sukoharjo, Tirtomoyo, Wonogiri. 


\section{DAFTAR PUSTAKA}

Hidayat, P. dan Darwin P. 2008. pengaruh dosis kompos pupuk kandang sapi terhadap pertumbuhan dan produksi buah tomat, (Skripsi S-1 jurusan budidaya pertanian fakultas pertanian Universitas Lampung

Setiawan Ade Iwan. 1998. Memanfaatkan kotoran ternak. Penebar Swadaya Jakarta.
Rahardi F, Sri N, Eko M. 1995. Bercocok Tanam dalam Pot. Penebar Swadaya Jakarta.

Zulkarnain. 2009. Dasar-dasar Holtikultura. Penerbit PT. Bumi Aksara, Jakarta. 